\title{
Rolling corals in the Mediterranean Sea
}
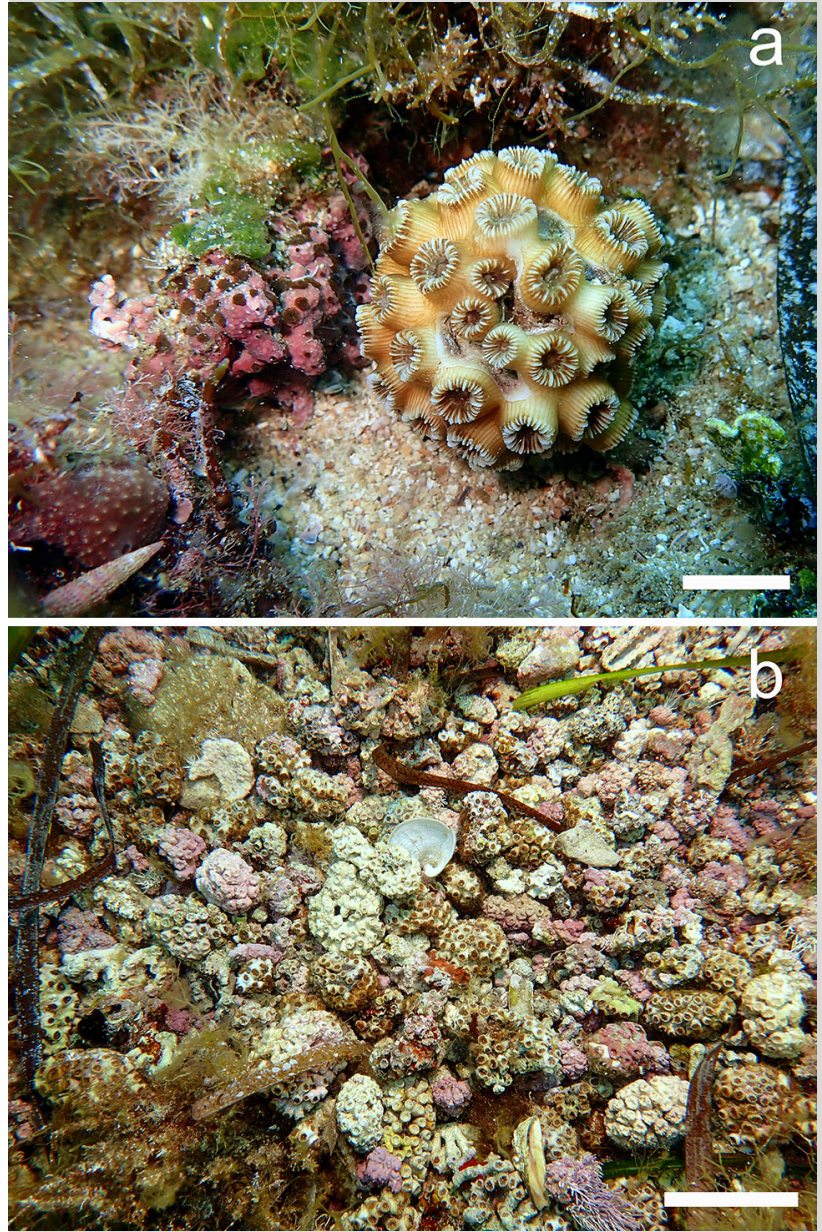

Fig. 1 a Coral nodule or corallith (Cladocora caespitosa). Scale bar $1 \mathrm{~cm}$. b Mixed accumulation of coral and coralline algae nodules in a rocky depression. Scale bar $10 \mathrm{~cm}$
Nodular morphology is typical of free-living coralline algae (Rhodophyta), which form extensive rhodolith beds worldwide over broad latitudinal and depth ranges (Foster 2001). Strikingly, under certain environmental conditions, coral colonies may also be able to live unattached to the substratum, as has been reported in the Atlantic, Indian and Pacific oceans (Glynn 1974; Roff 2008; Capel et al. 2012). Here, we report the occurrence of nodules of the Mediterranean endemic reef-building coral Cladocora caespitosa in Formentera (Balearic Islands, Mediterranean Sea). Cladocora caespitosa builds globose to hemispherical colonies that form banks and beds (Peirano et al. 1998). On the islet of Espardelló (Formentera), C. caespitosa colonies make unique beds composed mainly of small colonies (under $10 \mathrm{~cm}$ in diameter) that occur in high densities on a rocky bottom dominated by erect macroalgae (mainly Cystoseira spinosa) between 6 and $14 \mathrm{~m}$ depth. Many of the coral colonies are unattached and display a nodular morphology characterized by spherical growth (i.e., polyps growing in all directions) (Fig. 1a). These coral nodules or coralliths occur among algae on mixed rock and coarse sand bottoms and accumulate in high numbers in depressions, together with coralline algal rhodoliths (Lithophyllum racemus, L. coralloides and other species) (Fig. 1b). We hypothesize that this unusual coral morphology may be the result of periodical wave-induced turnover of small coral colony fragments inside the algal forest. Coralliths are found alive inside the algal forest, while living and totally or partially dead coralliths are found together in the rocky depressions where frondose macroalgae are absent (Fig. 1b). This is the first report of high abundances of free-living nodular corals in the Mediterranean Sea.

Acknowledgments MPA and Natural Park of Freus d'Eivissa i Formentera.

\section{References}

Capel KCC, Segal B, Bertuol P, Lindner A (2012) Corallith beds at the edge of the tropical South Atlantic. Coral Reefs 31:75 Foster MS (2001) Rhodoliths: between rocks and soft bottoms. J Phycol 37:659-667

Glynn PW (1974) Rolling stones amongst the Scleractinia: mobile coralliths in the Gulf of Panama. Proc 2nd Int Coral Reef Symp 2:183-198

Peirano A, Morri C, Mastronuzzi G, Bianchi CN (1998) The coral Cladocora caespitosa (Anthozoa, Scleractinia) as a bioherm builder in the Mediterranean Sea. Memorie Descrittive della Carta Geologica d'Italia 52:59-74

Roff G (2008) Corals on the move: morphological and reproductive strategies of reef flat coralliths. Coral Reefs 27:343-344

D. K. Kersting (囚)

Departament d'Ecologia, Universitat de Barcelona, Barcelona, Spain

e-mail: diegokersting@gmail.com

D. K. Kersting

AG Geobiologie und Anthropozänforschung, Institut für Geologische Wissenschaften, Freie Universität Berlin, Berlin, Germany

E. Cebrian $\cdot$ J. Verdura

Departament de Ciències Ambientals, Universitat de Girona, Girona, Spain

E. Cebrian $\cdot$ J. Verdura $\cdot$ E. Ballesteros

Centre d'Estudis Avançats de Blanes, Blanes, Spain

Received: 9 June 2016/Accepted: 26 August 2016/Published online: 20 September 2016

Coral Reefs (2017) 36:245

(C) Springer-Verlag Berlin Heidelberg 2016 